\title{
From explicit to implicit orientation: mapping rank scale to modality in English and Chinese
}

\author{
Shu-Kun Chen
}

\author{
Correspondence: \\ shukunchen@gduf.edu.cn \\ This paper was presented at the \\ 44th International Systemic \\ Functional Linguistic Congress \\ School of Foreign Languages and \\ Cultures, Guangdong University of \\ Finance, Guangzhou 510520, China
}

\begin{abstract}
In Systemic Functional Grammar, modality is treated as a semantic domain that extends across more than one grammatical environment. The basic distinction that determines various realizations of modality is modeled as the system of ORIENTATION. This paper aims to compare the explicit/implicit manifestations of modality in English and Chinese, a relatively less discussed issue in previous literature. After introducing the system network of modality in SFG, the paper, based on the rank theory, posits that the explicit/implicit orientation could be mapped clearly onto the choices of three ranks: clause, phrase/group and word. A meaning-oriented criterion is set up as follows: (i) Explicit modality is construed as Figure/Proposition; (ii) Quasi-explicit modality is construed as projecting Circumstance; (iii) Implicit modality is construed as modal Adjunct, part of Process/Predicator or mood element. Provided this criterion, various realizations of modality are examined along the rank scale both in English and Chinese. It is found that the two languages share similar lexicogrammatical strategies in this respect. Some major differences are: (i) Verbal groups (e.g. shuō bú ding 'say NEG firm') can be used to construe implicit modality in Chinese. This phenomenon is not found in English. (ii) In English, the choice of explicit and implicit modality parallels the choice of subjective and objective modality. In Chinese, however, the choice of subjective and objective modality is available only when explicit modality is opted. A small-scale analysis of how modality is translated in a parallel corpus shows preliminary evidence for the above observations.
\end{abstract}

Keywords: Modality, Orientation, Rank, Explicit, Implicit, Subjective, Objective

\section{Introduction}

Modality has long been an important issue in linguistics (e.g. Lyons 1977; Quirk et al. 1985; Bybee et al. 1994; Palmer 2014). It has also been one of the central concerns in Chinese linguistics (e.g. Tsang 1981; Xu 2000; Peng 2005). And the comparison of modality in English and Chinese is not new (e.g. Li 2004). However, this paper will show that there is still some room for further comparison of modality in the two languages under the framework of Systemic Functional Grammar (hereafter SFG). In SFG, modality is regarded as a semantic domain that extends across varied grammatical units. The basic distinction that determines various realizations of modality is modeled as the system of ORIENTATION (Halliday and Matthiessen 2014: 692) or MANIFESTATION (Matthiessen 1995). Despite emerging attempts to investigate modality in Chinese from the

(c) The Author(s). 2017 Open Access This article is distributed under the terms of the Creative Commons Attribution 4.0 International License (http://creativecommons.org/licenses/by/4.0/), which permits unrestricted use, distribution, and reproduction in any medium provided you give appropriate credit to the original author(s) and the source, provide a link to the Creative Commons license, and indicate if changes were made. 
SF perspective (e.g. Zhu 1996; Li 2007; Wei 2008; Yang and Chang 2011), the system of ORIENTATION has not been fully discussed. Therefore, the present study aims to supplement the previous literature by examining whether the system of ORIENTATION could be applied to the description of modality in Chinese. This is what Matthiessen (2015) calls 'transfer comparison' in designing a study of language description. Two questions will be addressed in this study:

How is modality manifested explicitly and implicitly in English and Chinese?

What are the choices in the system network of ORIENTATION of modality in Chinese?

For a more systematic comparison, the hypothesis of rank theory in SFG will be adopted to establish an analytical framework. The structure of the paper is as follows. First, the theoretical background of modality and rank scale in SFG will be reviewed. It is followed by a proposal of meaning-oriented criterion for various explicit/implicit manifestation of modality based on explicit and implicit realizations of modality in English. Then this criterion will be used to examine realizations of modality in Chinese. Next, the subjective and objective variants of modality will be discussed. Finally, the explicit and implicit modality will be investigated based on a small sample data from an English-Chinese parallel corpus. It should be noted in the beginning that because the focus of this study is on the system of ORIENTATION, only probability but not all modality types will be discussed.

\section{Theoretical background}

Modality is modeled as a system of choices for construing uncertainty between yes and no in SFG. Halliday and Matthiessen (2014: 182) present the system network in Fig. 1 below:

The system of MODALITY TYPE represents the choice of a proposition or a proposal. The system of ORIENTATION represents the choice of various realizations. The system of VALUE represents the degree of uncertainty. The system of POLARITY represents the choice of yes and no. The current study focuses on ORIENTATION. There are two dimensions in the system of ORIENTATION: subjective/objective variants and explicit/ implicit variants. Thompson's (2014: 73) illustration of the subjective/objective variants is most straightforward:

One feature that the different realizations of modality have in common is that they can be graded according to how far the speaker overtly accepts responsibility for the attitude being expressed. Essentially, speakers may express their point of view in a way that makes it clear that this is their subjective point of view; or they may do it in a way that 'objectivizes' the point of view by making it appear to be a quality of the event itself.

The explicit/implicit variants, on the other hand, represent the choice of whether modality is realized as a separate clause or as part of a clause (Thompson 2014: 75; Halliday and Matthiessen 2014:181; Martin et al. 2010: 67-69). Matthiessen (1995: 497) considers it as a system of MANIFESTATION. The four features combine to generate various realizations of modality as shown in Table 1.

The relevance between explicit/implicit modality and rank scale is illustrated through the notion of interpersonal metaphor by Halliday and Matthiessen (2014: 698). Explicit modality is a metaphoric strategy of interpersonal assessment: 


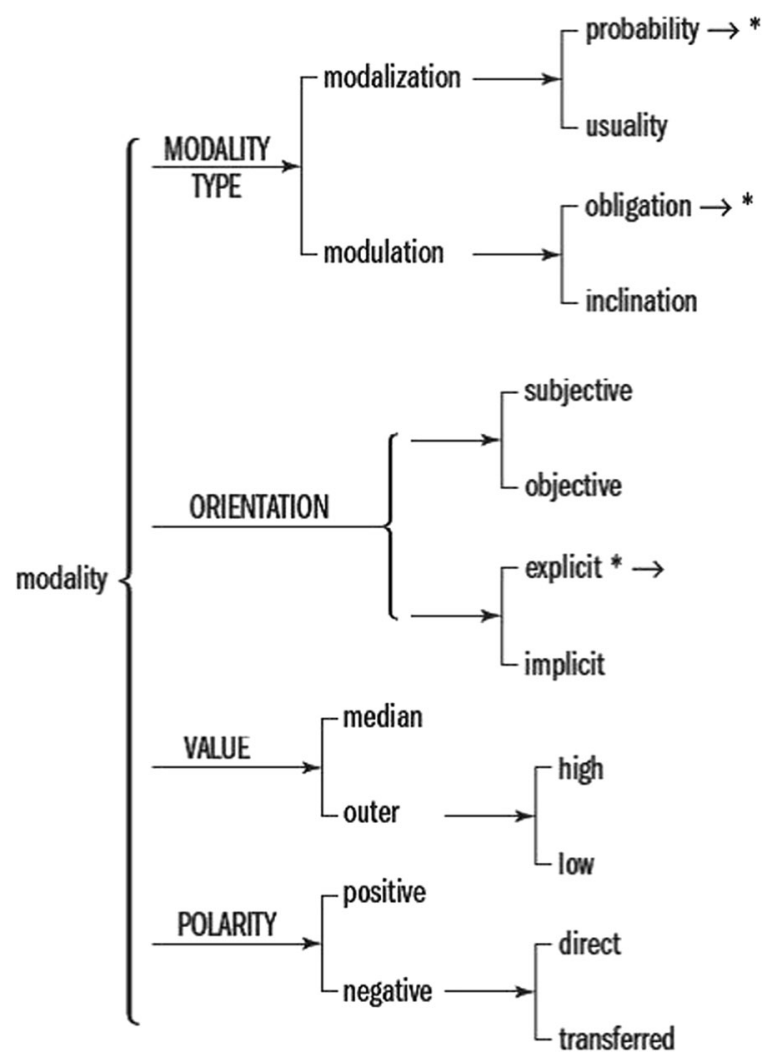

Fig. 1 System network of modality (Halliday and Matthiessen 2014: 182)

The metaphoric strategy is to upgrade the interpersonal assessment from group rank to clause rank - from an adverbial group or prepositional phrase serving within a simple clause to a clause serving within a clause nexus of projection.

Therefore, in explicit modality, we could identify modal assessment realized at the clause rank. Implicit modality, on the other hand, is realized at the group rank. However, it should be noted that the explicit/implicit dimension is a cline in which some realizations lie somewhere in between. In English, prepositional phrases such as in my opinion are used to realize the intermediate explicit/implicit modality. For descriptive convenience, this type of realization will be called "quasi-explicit" modality. Halliday and Matthiessen (2014: 688) explain that a phrase is "a kind of halfway house between clausal and non-clausal status." It could be interpreted more clearly in light of the rank theory.

The rank theory is another basic assumption of SFG. It posits that language is organized by units at different ranks on a scale from highest-ranking to lowest-ranking according to their constituency potential (Matthiessen 1995: 75; Thompson 2014: 21-26). A unit of higher rank consists of units of the rank next below. In English, the rank scale is 'clause group/phrase - word - morpheme', as exemplified in Table 2 below.

Table 1 Four feature combinations of realizations of modality (Halliday and Matthiessen 2014: 181)

\begin{tabular}{lll}
\hline & subjective & objective \\
\hline implicit & must & Certainly \\
explicit & I am certain that ... & It is certain that ... \\
\hline
\end{tabular}


Table 2 Rank scale modeled in SFL (Matthiessen 1995: 75)

\begin{tabular}{ll}
\hline RANK & Examples \\
\hline clause & What enables us to have thoughts and feelings? | \\
group/phrase & What| enables ... to have| us $\mid$ thoughts and feelings \\
word & What $\mid$ enables, ... to, have| us| thoughts, and, feelings \\
morpheme & What $\mid$ enable $+s, \ldots$ to, have| us $\mid$ thought $+s$, and, feel + ing $+s$ \\
\hline
\end{tabular}

Different from traditional approaches, SFG emphasizes the difference between a phrase and a group. A prepositional phrase differs from a group in the sense that a phrase is a reduction of a clause (or a minor/mini clause) whereas a group is an expansion of a word. In experiential line of meaning, the internal structure of a prepositional phrase can be separated into (minor) Process and Range, as shown below (Table 3):

"The nominal group in a prepositional phrase", as Halliday (1994: 213) suggests, "corresponds in function to one or other of the participants Range, Goal, Attribute, though without any very clear distinction among them." Thus he interprets the nominal group in all cases of prepositional phrases as Range. In the interpersonal line of meaning, the preposition plays the function of Predicator while the nominal group serves as Complement. Therefore, the internal structure of a phrase could be analyzed with the same logic as that of a clause. The structure of a group, on the other hand, displays a 'Modifier ^ Head' pattern. Hence it is more like an expanded word than a reduced clause. From this perspective, a prepositional phrase in my opinion is functionally related to I think. Therefore, it should be regarded as quasi-explicit modality.

Another critical theoretical concept is rankshift, which means units at the higher rank come to serve as if they were units of lower ranks. For example, a clause may be rankshifted to function as a Modifier of a Head in a nominal group as in As a simple illustration, think of an intern [[who examines a patient in the emergency ward of a hospital]] (the rankshifted clause is marked by [[]] while the rankshifted group is marked by []) (see Matthiessen 1995: 99-100). Rankshift is a vital grammatical means for expanding the meaning potential of units at the lower rank. Now with the notion of rank-scale, it becomes clear that various manifestations of modality could be described with reference to various ranks.

\section{Examining explicit/implicit modality along the rank-scale in English}

The previous section gives an overview on how explicit/implicit modality is related to the clausal status of a grammatical unit, which in turn is pertinent to how different rank levels are modeled in SFG. This interconnection makes it possible to map the rank-scale on the explicit/implicit cline of modality. However, it is necessary to establish a functional or meaning-oriented criterion for determining whether modality is explicit or implicit so that it could be used to account for both congruent and incongruent realizations of modality. The overall principle is as follows:

Table 3 Representation of prepositional phrases

\begin{tabular}{llll}
\hline the boy & stood & on & the burning deck \\
Actor & Process & Location & \\
& & Process & Range \\
\hline
\end{tabular}


Explicit modality is construed as Figure/Proposition.

Quasi-explicit modality is construed as projecting Circumstance (or more specifically, Angle).

Implicit modality is construed as modal Adjunct, part of Process/Predicator or mood element.

Table 4 demonstrates how the rank scale could be mapped onto functional units and the explicit/implicit realizations of modality. Though phrase and group are both considered to be the constituencies of a clause next below, they differ in terms of their resemblance to the structure of a clause (as stated earlier). This is the major feature that separates explicit and implicit variants of modality because only the former pattern could bring out the meaning potential of projecting circumstance (e.g. in my opinion). Moving down the rank scale, modality could be realized by a unit at the group rank and at the word rank. At the group rank, it is often realized by adverbial groups such as very probably. At the word rank, the modal operator should is a finite in the verbal group. The term 'quasi-explicit' is used to describe the modality realized at the phrase rank to highlight the relatedness between a phrase and a clause. The expression in my opinion could be viewed as circumstantiation of the clause I think. It is what Halliday and Matthiessen (2014) call Angle. Angle behaves quite similarly to a projecting clause and is more semantically detached from the main clause compared with other types of circumstance (e.g. manner) (see Chen 2016 for comparison between English and Chinese in this respect). Hence, the general principle is that grammatical units at higher ranks realize more explicit modality than those at lower ranks.

Some cases involving rankshift are worth a few comments. Explicit modality can happen when a clause to be modalized is rankshifted as a nominal group as shown below:

[3.1a] My opinion is [[that they want amnesty here]]. This is just another step towards amnesty (COCA).

[3.1b] What [[I believe]] is that this trial has tremendous ramifications for all of us. (COCA)

In example 3.1a, modality is construed not as part of evaluated clause they want amnesty here, but as a relational clause. In other words, modality is construed as a figure including a participant My opinion and a relational process is. By the same token, in example $3.1 \mathrm{~b}$, modality is construed as a figure entailing a participant What I believe, in which a mental clause is rankshifted to serve as if it were a nominal group, and a relational process is.

[3.2] The way [[I see it]], we've got three choices (COCA FIC).

Example 3.2 shows another peculiar case of rankshift. Here, modality is realized by a nominal group The way I see it. However, the whole expression functions as an angle, in which the mental clause is downranked to qualify the nominal group The way. It is a

Table 4 Examples of explicit and implicit realizations of probability along the rank-scale in English

\begin{tabular}{|c|c|c|c|c|}
\hline Rank scale & Interpersonal unit & Experiential unit & Explicit/implicit cline & Examples of probability \\
\hline clause & Proposition & Figure & explicit & I think / My opinion is that ... \\
\hline phrase & & $\begin{array}{l}\text { projecting } \\
\text { Circumstance }\end{array}$ & quasi-explicit & in my opinion \\
\hline group & $\begin{array}{l}\text { modal Adjunct/ } \\
\text { Predicator }\end{array}$ & Process & implicit & probably / be likely to \\
\hline word & Finite & & implicit & should \\
\hline
\end{tabular}


projecting circumstance that is realized by a nominal group rather than the typical prepositional phrase (e.g. in my opinion). Hence, a meaning-oriented criterion as proposed above could better account for such atypical manifestations of modality. Nonetheless, the rank-scale could serve as an analytical framework for an examination on manifestations of modality in other languages like Chinese. It can also be applied to the analysis of how modality is translated, as will be shown below.

\section{Examining explicit/implicit modality along the rank-scale in Chinese}

The last section sets forth the corresponding relation between units of various rank levels, functional units, and explicit/implicit manifestations of modality in English. More importantly, a meaning-oriented criterion has been established. Now this approach will be applied to the analysis of modality in Chinese. In other words, various manifestations of modality will be examined along the rank-scale. But first, it is necessary to mention a few relevant typological features of Chinese language.

Chinese and English share the number of units on the rank scale. However, there are at least two differences as pointed out by Halliday and McDonald (2004: 312-314):

First, in Chinese the lowest rank with implications for clause grammar is the group rather than the word. The internal structure of the word is strictly derivational (compounds, word class formatives) rather than inflectional. Grammatical affixes (usually known as particles) can be analysed as part of the structure of either the group (subordination, aspect) or the clause (aspect, mood). This means that the conception of rank scale is a little different from English in that some word classes operate directly in the structure of the clause. Secondly, there is a degree of functional indeterminacy between certain ranks $[. .$.$] this often makes it difficult to distinguish between verbal$ group and clause, and between verbal group complex and clause complex.

The indeterminacy between certain ranks poses challenges for analyzing the explicit/ implicit variants of modality in Chinese. For example, a 'Pedicator ^ Complement' structure like yǒu kènéng '有可能, have possibility' might be treated as an existential clause (meaning 'have possibility') or a compound word (meaning 'probably') depending on specific grammatical environments.

Another noteworthy feature is that the preposition in Chinese is also known as 'coverb' because it generally originates from verbs and often form the coverbial/coverbal phrase that co-occurs with the main verb in a clause (Li and Thompson 1989: chapter 9). For example:

[4.1] wǒ yào gēen tā shuōhuà.

我要 跟他说话

I want with him talk.

"I want to talk with him."

The verb nature of prepositions in Chinese conforms to Halliday's (1994:213) assumption that preposition is a 'mini-verb' that realizes the experiential function of 'minor process'. It is also referred to as 'prepositive verb' by Halliday (1956). The only class of phrase in Chinese, as $\operatorname{Li}(2007$ : 32-34) suggests, is the coverbal phrases in the structure of 'coverb ${ }^{\wedge}$ nominal group'. Two types of coverbal phrases are recognized: 1 ) Circumstantial type - which corresponds roughly to various types of Circumstance in 
English; and 2) Participant type - which realizes a participant in a figure: Beneficiary in a ditransitive clause, Goal or Actor in a clause with dispositive voice (e.g. bă, bèi, gěi and ràng). If Li's assumption is correct, the congruent form of quasi-explicit modality in Chinese should be coverbal phrases.

Now with the two typological features in mind, various realizations of modality in Chinese will be examined along the rank scale below.

\section{Clause rank: Explicit modality}

Explicit modality is construed as projecting figures in Chinese. Below are two typical examples:

[4.2a] wò rènwéi tā zài jiā.

我认为他在家

I think he at home.

'I think he is home.'

[4.2b] kèlè gèrén gănjué nı̌ zhè kuăn xiāngshuı̌ bú shihé nǔ.

可乐, 个人 感觉你 这款 香水 不适合 你

NAME personal feel you this MEA perfume NEG fit you.

'Ke Le, I feel that this perfume does not fit you.'

Similar to English, explicit realization of modality might be complicated by rankshift.

For example, a mental clause might be packaged as a nominal group as shown below:

[4.3] wǒde kànfã shì [[tā zài jiā]]].

我的看法是 他 在 家

my opinion be he at home.

'My opinion is that he is home.'

The clause may also be downranked to serve as Qualifier. For example:

[4.4] zhè jiù shì [[wǒ rènwéi de]] zuì jiăndān ér yǒuxiào de bànfă.

这就是我认为的最简单而有效地办法。(BCC)

this just be I think SUB most simple and effective SUB solution.

'I think this is the most simple and effective measure.'

The peculiarity in Chinese is that the downranked mental clause should precede other Qualifiers. We cannot say.

[4.5] "zhè jiù shì zuì jiăndān ér yǒuxiào de [[wǒ rènwéi de $]]$ bànfá.

这就是最简单而有效地我认为的办法

this just be most simple and effective SUB I think SUB solution.

The sequence of the qualifiers could be explained as follows: just like the explicit realization of modality, the modalization should be construed, as it were, outside of the modalized nominal group. In other words, the rankshifted mental clause projects the following units in the nominal group. And this logical-semantic relation is reflected in the sequence of qualifiers.

\section{Phrase rank: Quasi-explicit modality}

As mentioned above, the only phrase in Chinese is coverbal phrase. Quasi-explicit modality is construed as an angle realized by a coverbal phrase as shown below:

[4.6a] xiànzài, duì wǒ láishuō, zuìxingfú mòguòyú fēijī chūgùzhàng.

现在 对 我 来说 最幸福 莫过于 飞机 出故障 
now to me come-say luckiest no-more-than plane break-down.

'Now, the plane's breakdown is the best thing to me.'

[4.6b] búguò yĩ xuéshēng láikàn, zhèxiē dōu shì xìjié.

不过 依 学生看来 这些都是 细节

but acc. Student(myself) come-see these all be detail.

'But in my opinion, these are all details.'

The common pattern is that the coverb combines with a verbal group to formulate a coverbal complex (the circumposition in the sense of Greenberg 1995; Liu 2002; Cai 2013). In example 4.6a, the coverbal complex is dui ... láishuō. In example 4.6b, the complex is yī...láikàn. Another pattern is that a mental clause serves as Complement as in $y \bar{\imath}$ wǒ kàn, in which wǒ kàn is a mental clause.

Notably, in Chinese, the whole coverbal phrase could be put after the conditional connectives such as rú, rúguó, ruò or yào 'if'. For example:

[4.7a] rú yĩ wǒde yìsī, bùrú yòng liángshuı̌ bă tā guànxǐng.

如 依 我的 意思不如 用 凉水 把 他 灌醒

if acc. my way why-not use cold-water PAR he pour-wake.

'If you ask me, why not pour her awake with cold water.'

[4.7b] rú yì wǒ kàn, juéduì shì yǒu fēi dí.

如依我看绝对是友非敌

if acc. I see absolutely be friend not enemy.

'If you ask me, it is definitely a friend not an enemy.'

It could be argued that the coverb $y \bar{\imath}$ in the data above is used as a verb. However, the Subject of the verb $y \bar{\imath}$ would never occur in this structure. For example, we cannot say rú ň̌ yì wǒ kàn 'If you acc. I see'. It means that the conditional clause is used specifically for introducing the speaker's own advice. In this case, it could be treated as explicit or quasi-explicit modality.

\section{Group rank: Implicit modality}

In Chinese, implicit modality is construed as a modal adjunct. It could be realized by an adverbial group in which a modal adverb serves as Head. The typical items are kěnéng '可能 probably' and yěxŭ '也许 perhaps'.

It should be noted in particular that in Chinese, a clause can be downranked to become a word (somewhat similar to lexicalization). First consider the case of yǒu kěnéng '有可能 have possibility'. It could be analyzed as an existential clause where yóu 'have' is the existential process and kénéng 'possibility' is the existent. See the examples below:

[4.8a] tā kènéng zài jiāa.

他可能在家

he probably at home.

'He is probably home.'

[4.8b] tā yǒu kěnéng zài jiā.

他有可能在家

he have possibility at home.

'He is probably home.'

[4.8c] tā hěn yǒu kènéng zài jiā.

他很 有可能 在 家 
He very have possibility at home.

'He is very probably home.'

[4.8d] tā yǒu diăn kénéng zài jiā.

他有点可能在家

He have little possibility at home.

'There is a little probability that he is home.'

The existential clause yǒu kénéng is all downranked to serve as a word in $4.8 \mathrm{~b}$ to $4.8 \mathrm{~d}$. Actually, it could be argued that yǒu kènéng is a fully lexicalized word. The grammatical feature of yǒu kénéng is comparable to that of yǒu yòng 'have use', which is a typical adjective meaning 'useful'. They can both be modified by hěn 'very' as in hěn yǒu kěnéng 'very probably' and hěn yǒu yòng 'very useful'. They can be both modified by diăn 'little' in the middle as in yǒu diăn kènéng 'a little probability' and yǒu diăn yòng 'a little useful'. Therefore, it is not necessary to treat yǒu kènéng as a rankshifted existential clause. But rather, it is a word that serves as Head of the adverbial group which realizes modal Adjunct in the examples above. In example 4.8b, there is no Modifier. In example 4.8c, the Modifier is hèn 'very'. In example 4.8d, the Modifier is diăn 'little'. Therefore, yǒu kěnéng is an adverbial group that functions as modal Adjunct in the examples above.

Further evidence to treat yǒu kěnéng as modal Adjunct is shown in example 4.9 below:

[4.9] tā yěxŭ yǒu kènéng zài jiā.

他也许有可能在家

he perhaps have possibility at home.

'He may probably be home.'

Two modal adjuncts yěxŭ 'perhaps' and yǒu kěnéng 'probably' are put together to form a complex. It indicates that the two units are of the same kind. Therefore, you kénéng is considered as realizing implicit modality when it occurs in a clause.

In Chinese, some mental verbs can be used to construe modal Adjunct such as kǒngpà '恐怕fear'. For example:

[4.10] tā kóngpà bú zài jiā.

他恐怕不在家

he probably(afraid) NEG at home.

'He is probably not home.'

More interestingly, some verbal groups are composed of, typically, a projecting verb and a postverb (e.g. shuō bú ding '说不定 say NEG firm'). This structure is more often considered as completive verb compounds in traditional grammar (e.g. Thompson 1973). McDonald (1996), from the perspective of rank-scale in SFG, regards this structure as a verbal group. His general argument is that the complement in a verb compound should be functionally viewed as Extension of the verb that expresses phasal meanings. Thus a verb compound simultaneously works at the clause rank as Process and at the verbal group rank as a verb plus a postverb. It can be better illustrated with a simple clause in Table 5 below:

Extension here is used as a functional label representing combinations of semantic choices in the system of PHASE. According to McDonald, the system of PHASE, in contrast with the system of ASPECT, concentrates more specifically on the Process. It "identifies separate stages of progression of the action." Therefore, in Chinese, we have 
Table 5 Experiential structure of a clause with a verb compound

\begin{tabular}{llll}
\hline wǒ & xí & hăo & $l e$ \\
I & wash & good & \\
Actor & Process (material) & & \\
nominal group & verbal group & & Aspect \\
& Event & Extension & particle \\
& verb & postverb &
\end{tabular}

compounds like xiăngqùlái '想起来come up with an idea', zǒuxiàqù '走下去continue to walk', zuòwán '做完be finished', etc. McDonald argues that the system of PHASE in Chinese should include three basic choices of meaning: directional, resultative as well as non-literal directional as shown in Fig. 2 below:

Under this framework, the verbal group shuō bú ding could be analyzed as 'verb ^ postverb' structure. The postverb bú ding denotes the mental state of uncertainty. Consider the data below:

[4.11a] wòmén shuō bú dìng shènme shíhòu jiù yào líkāi.

我们说不定什么时候就要离开

we say NEG firm what time just should leave(BCC Literary).

'We are not sure when we should leave.'

[4.11b]? wǒmén shènme shíhòu jiù yào líkāi.

我们什么 时候 就 要 离开

we what time just should leave.

'When should we leave?'

[4.11c] y̌̌hòu wòmén shuō bú ding huì chéngwéi péngyǒu.

以后我们说不定会变成朋友 (BCC Literary)

later we say NEG firm will become friend.

'We will probably become friends in the future.'

[4.11d] y̌̌hòu wòmén hui chéngwéi péngyǒu.

以后 我们会变成 朋友

'We will become friends in the future.'

In example 4.11a, the verbal group shuō bú ding roughly means 'don't know' or 'cannot decide'. It cannot be reduced because it is still experientially significant, playing the function of mental process in the clause. However, the expression shuōbúding in example 4.11c

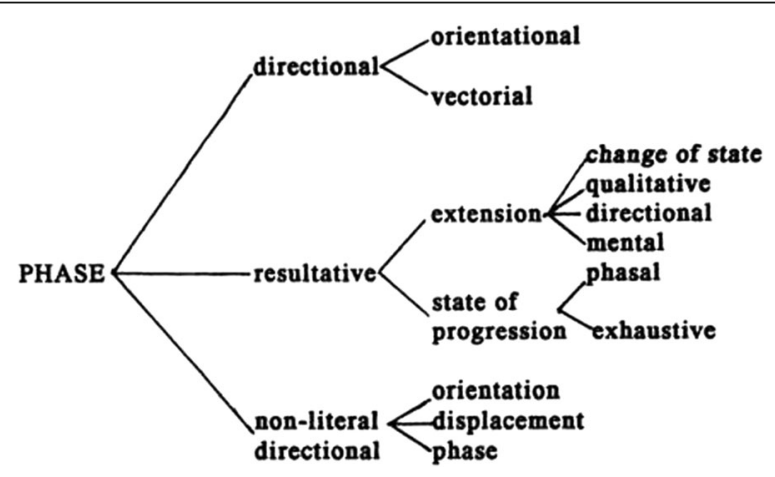

Fig. 2 System of phase in Chinese (McDonald 1996:324) 
should be analyzed as modal Adjunct rather than verbal Process because it is experientially insignificant. It is deductible as shown in example 4.11d. But from example 4.11c to example 4.11d, the meaning of probability is lost. It could be theorized as decategorialization in the sense of Hopper and Traugott (1993: 102). In SFG, this could be modeled as change of its metafunction from experiential projection (meaning don't know) to interpersonal projection (meaning probably).

Another item that could be analyzed in a similar way is méi zhŭn '没准NEG accurate'. It is a verbal group serving as Attribute in example 4.12a but as modal Adjunct in example 4.12b below:

[4.12a] zhè huǒchē méi zhŭn.

这火车没准

this train NEG accurate (BCC Literary).

'This train is not on time.'

[4.12b] méi zhŭn yìhuì jiù huì xiàyŭ.

没准一会就会下雨 (BCC Literary)

NEG accurate soon just will rain.

'It will probably rain soon.'

The common feature of these groups is that they cannot be modified by degree adverbs. We cannot say hěn shuōbúding (很说不定) or hěn méizhǔn (很没准) for modal assessment. The only exception is that they can be modified by the verbal adjunct $y e ̌$ 'also' when the group occurs at the end of a clause. For instance:

[4.13a] wǒmén huì biànchéng péngyǒu yě shuōbúding.

我们会变成朋友也说不定

we will become friend also probably.

'It is also possible that we will become friends.'

[4.13b] yíhuì jiù huì xiàyŭ yě méizhŭn.

一会就会下雨也没准

soon just will rain also probably.

'It is also possible that it will rain in a while.'

Here the placement of the groups is textually motivated. The textual meaning is to construe modality as NEW. It is similar to the evaluative enhanced construction "it is ... that", e.g. it is also possible that, in English (Fawcett and Huang 1995, Wang 2008). Without this kind of grammatical construction in Chinese, the post position of a group is a more common strategy. The verbal groups could not be considered as realizing events because no Participant is involved. Hence, they realized implicit modality.

\section{Word rank: Implicit modality}

Down to the word rank, implicit modality is construed as verbal adjunct which is realized by modal auxiliaries ${ }^{1}$ such as yinggai i '应该should'. Modal auxiliaries serve as premodifiers in verbal groups. See the example below:

[4.14a] tā yīnggāi zài jiā.

他应该在家

He probable at home.

'He should be home.' 


\section{[4.14b]? yīnggāi tā zài jiā.}

应该他在家

probable he at home.

The modal assessment is realized by the verbal auxiliary. Hence it cannot be moved to the initial position of the clause as illustrated in example $4.14 \mathrm{~b}$. Another way to realize implicit modality is to use the mood particle $b a$ (see Zhu 1996). Now manifestations of modality at various ranks in Chinese are summarized in Table 6 below:

\section{Subjective/objective modality along the rank-scale in English}

The subjective and objective orientations of modality can also be examined along the rank-scale. In this way, the interaction between explicit/implicit and subjective/objective dimensions could be more clearly revealed. Table 7 displays the interaction with the examples of probability in English. To simplify the matter, cases that involve rankshift are not included.

It is interesting to note that the choice of subjective and objective orientations of modality mostly parallels the choice of explicit and implicit variants. However, at the group and word ranks, some choices are missing. It is so because the subjective orientation of implicit modality is defined based on the criterion that whether the modality could be probed by the speaker. Modality that is realized by the verbal operator (at the word rank, e.g. must) can be probed as in Must he have left? and therefore it is subjective. On the other hand, modality that is realized by the adverbial group (at the group rank, e.g. certainly) cannot be probed this way, so it is objective (Halliday and Matthiessen 2014: 181).

Also noteworthy is that when the manifestation of modality moves from implicit to explicit, the meaning potential could be further expanded, catering to interpersonal needs. For example, the explicitly-subjective modality could be realized as a conditioning clause as shown below:

[5.1] That sounds like an opportunity for perversion if you ask me. (COCA FIC).

Conditioning clauses like these are regarded as idioms that mean in my opinion in English (Chang 2017: 325). With this expression, not only is the subjective orientation foregrounded, but some sense of politeness or social distance is also added. This effect cannot be achieved with the units at group or word ranks.

Table 6 Manifestations of probability along the rank-scale in Chinese

\begin{tabular}{|c|c|c|c|c|}
\hline Rank-scale & Interpersonal unit & Experiential unit & Orientation & Examples of probability \\
\hline clause & Proposition & Figure & explicit & $\begin{array}{l}\text { wǒ kàn } \\
\text { 我 看 } \\
\text { wǒde kànfă shì ... } \\
\text { 我的 看法 是 } \\
\text { wǒ rènwéi de... } \\
\text { 我认为的... }\end{array}$ \\
\hline phrase & & projecting Circumstance & quasi-explicit & $\begin{array}{l}\text { zài wǒ kànlái } \\
\text { 在我看来 }\end{array}$ \\
\hline group & modal Adjunct & & implicit & $\begin{array}{l}\text { kěnéng可能/yǒukěnéng有可能 } \\
\text { yěxǔ也许 } \\
\text { kǒngpà 恐怕 } \\
\text { shuōbúding说不定 } \\
\text { méizhǔn没准 }\end{array}$ \\
\hline \multirow[t]{2}{*}{ word } & verbal Adjunct & & implicit & yīnggäi应该 \\
\hline & mood element & & implicit & $b a$ 吧 \\
\hline
\end{tabular}


Table 7 Interaction between explicit/implicit and subjective/objective orientations of modality (excluding cases that involve rankshifting)

\begin{tabular}{llll}
\hline Rank & Manifestation & Subjective & Objective \\
\hline clause & explicit & I am certain & It is certain that \\
phrase & quasi-explicit & in my opinion & in all probability \\
group & implicit & - & certainly \\
word & implicit & must & - \\
\hline
\end{tabular}

Another case in point is the quasi-explicit modality in my opinion. With the halfclausal structure, some evaluative meanings could be added to further moderate the modal value. See the data from COCA in Table 8:

In the expressions like IN MY HUMBLE OPINION, the modal value of the main clause would be downgraded. However, what the usage really reflects is the social distance between the speaker and the addressee. We can hardly picture two intimate friends uttering out the expression in my humble opinion. On the contrary, expressions like IN MY PROFESSIONAL OPINION tones up the modal value of the main clause by the positive item PROFESSIONAL. Hence the meaning potential of modality could be multiply expanded with the manifestation going from implicit to explicit.

\section{Subjective/objective modality along the rank-scale in Chinese}

The choice of subjective and objective orientation is available for the modality that is realized at the clause rank in Chinese. Similar to English, the subjective orientation is realized by verbal/mental clauses while the objective orientation is realized by relational clauses. They could be exemplified as follows:

[6.1a] wǒ rènwéi tā zài jiā.

我认为他在家

I think he at home.

"I think he is home."

Table 8 Frequency of Viewpoint with evaluating items in COCA

\begin{tabular}{lll}
\hline no. & itemS & freq. \\
\hline 1 & IN MY HUMBLE OPINION & 56 \\
2 & IN MY PERSONAL OPINION & 29 \\
3 & IN MY PROFESSIONAL OPINION & 16 \\
4 & IN YOUR PROFESSIONAL OPINION & 15 \\
5 & IN MY HONEST OPINION & 4 \\
6 & IN OUR HUMBLE OPINION & 3 \\
7 & IN YOUR HUMBLE OPINION & 3 \\
8 & IN HER PERSONAL OPINION & 2 \\
9 & IN HIS HUMBLE OPINION & 2 \\
10 & IN HIS PERSONAL OPINION & 2 \\
11 & IN MY CONSIDERED OPINION & 2 \\
\hline
\end{tabular}


[6.1b] - tā zài jiā.

他在 家

he at home.

'He is home.'

- yŏu zhè gè kènéng.

有这个可能.

have this MEA possibility.

'It is possible.'

The expression yŏu zhè gè kènéng in example 6.1b is an existential clause in which the existential process is yǒu 'have', and the existent is zhè gè kènéng 'this MEA possibility'. It is explicit modality because it could not occur in the middle of the modalized clause:

[6.2]* tā yǒu zhè gè kènéng zài jiā.

他有这个可能在家

he have this MEA possibility at home.

The existent kěnéng could also be graded by measure noun yì diăn '一点a little' as in yǒu yì diăn kènéng 'there is a little possibility'. This type of expression is often used as a response to others' statement rather than expressing the speaker's own attitude. And it could also be used as a question:

[6.3] yǒu méi yǒu zhè gè kènéng?

有没有这个可能?

has NEG has this MEA possibility.

'Is there such possibility?'

But when the existent is not modified, the rank level of the expression yǒu kěnéng is not clear. It behaves more like an adverbial group as it could occur in the middle of the modalized clause as already shown above. Hence the item yǒu kěnéng is analyzed as modal adjunct when it occurs as part of another clause.

At the phrase rank, it seems there is no objective orientation of modality. Similar to English, the meaning potential is also expanded through self-evaluation in angle. The most frequent evaluative items are listed in Table 9.

By and large, the evaluative items occur more frequently with more potential choices in Chinese angle than English.

For implicit modality, it is not necessary to distinguish subjective and objective orientations because there is no finite system in Chinese (Halliday and McDonald 2004).

Table 9 Frequency of evaluative viewpoints in BCC literary

\begin{tabular}{|c|c|c|}
\hline appraisal meaning & items & freq. \\
\hline \multirow[t]{3}{*}{ stupid/clumsy view } & yī ... (zhī) yú/zhuó jiàn & 552 \\
\hline & 依之愚/拙见 & \\
\hline & acc. SUB stupid opinion & \\
\hline \multirow[t]{3}{*}{ shallow view } & yī ... qiăn jiàn & 59 \\
\hline & 依 浅见 & \\
\hline & acc. shallow opinion & \\
\hline \multirow[t]{3}{*}{ narrow view } & yī ... yì kǒng zhĩ jiàn/guăn jiàn & 8 \\
\hline & 依一孔之见管见 & \\
\hline & acc. one hole SUB opinion/tube opinion & \\
\hline
\end{tabular}


Modality can be probed simply by adding the mood particle $m \bar{a}$ '吗' or tag question shi $m \bar{a}$ '是吗' at the end of the clause. For instance:

[6.4a] tā kènéng zài jiā mä?

他 可能在 家 吗?

he probably at home MOD.

'Might he be home?'

[6.4b] tā kènéng zài jiā, shì māa?

他 可能在 家, 是吗?

he probably at home be MOD.

'He might be home, might he not?'

The realizations of subjective/objective modality in Chinese are summarized in Table 10:

One prominent difference between Chinese and English is that the choices of objective modality are all missing at group and word ranks. Therefore, the system network of ORIENTATION in Chinese should be revised as in Fig. 3 below:

The network is reworked to highlight the fact that it is not necessary to distinguish subjective and objective orientations in implicit realizations of modality in Chinese. Only when explicit modality is chosen, the choice between subjective and objective orientations becomes available. It is so because the finite system of mood does not exist in Chinese. The evidence is that when the implicitly subjective and objective modality is translated from English, it is difficult to represent the difference in Chinese as illustrated below:

He may be home.

He is probably home.

Translation: tā kěnéng / yéxǔ / shuōbúdìng zài jiā.

他 可能 /也许 / 说不定 在 家.

While, in English, may and probably are subjective and objective respectively, the expressions in Chinese kěnéng, yéxǔ and shuōbúding behave similarly except that kénéng is gradable and the latter two are ungradable. They are not part of the finite (because there is no finite) or mood.

Is it possible to identify other criteria to judge the subjective orientation of the implicit modality in Chinese? Consider the example below,

[6.5] tā zài jiā ba.

他在家吧

he at home MOD.

'He is probably home.'

Table 10 Realizations of subjective/objective modality along the rank-scale in Chinese (excluding.cases that involve rankshifting)

\begin{tabular}{llll}
\hline Rank & Orientation & Subjective & Objective \\
\hline clause & explicit & wǒ kàn & yǒu zhè gè kènéng \\
& & I see & 有 这 个可能 \\
& & have this MEA possibility \\
phrase & quasi-explicit & zài wǒ kànlái & - \\
& & 在 我 看来 & \\
& at I see-come & - \\
group & - & - \\
word & implicit & - & \\
\hline
\end{tabular}




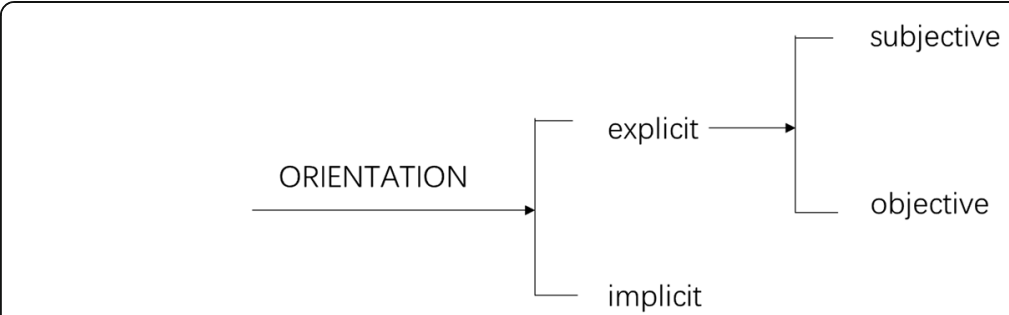

Fig. 3 System network of ORIENTATION of modality in Chinese

The mood particle $b a$ in example 6.5 signals the speaker's uncertain attitude. It is a case of utilizing the mood element (similar to the finite in English perhaps?) to give modal assessment in Chinese. Hence it could be viewed as implicitly subjective modality. But still, it could not be used in a systematic way like the finite in English (e.g. should for modulation and must for modalization). Hence the distinction between subjective and objective in implicit modality could not be justified. Similarly, in quasi-explicit modality, it appears that there is no expression in Chinese that is correspondent to the prepositional phrase in all probability. The translation is likely to be an adverbial group hěn kènéng 'very probably' or an idiom shí yǒu ba jiŭ '十有八九, literally, ten has eight nine'. The idiom is not a coverbal phrase but a lexicalized item that functions as modal Adjunct. It is more appropriate to treat the idiom as an adverbial group as well. In other words, no clear evidence supports the necessity to distinguish subjective and objective orientations in implicit modality in Chinese.

\section{Preliminary evidence in parallel corpus}

The previous sections have examined the explicit and implicit manifestations of modality in English and Chinese along the rank scale. However, more evidence is needed to justify the explicit/implicit categorization and the notion of quasi-explicit in particular. For this, we turn to translation. Matthiessen (2014) posits that translation (be it shift or equivalence) might be interpreted through dimensions of language organization: stratification, rank, instantiation, metafunction, delicacy, and axis (cf. Matthiessen 2001, 2014; Halliday 2009; Huang 2017). It is believed that drawing our attention to the dimension of rank may reveal the semantic features of various realizations of modality.

The sample data of the current study is collected from the English-Chinese parallel corpus of CCL. ${ }^{2}$ We have searched the corpus with three sets of key words: 'I think', 'in my opinion', and 'perhaps'. The three expressions are chosen because they are the most typical manifestations of explicit, quasi-explicit and implicit modality in English. Then the first 50 available instances of each expression are collected, generating a total number of 150 instances. How these expressions are represented in Chinese is shown in Table 11:

Table 11 Representation of 'I think', 'in my opinion' and 'perhaps' in parallel corpus

\begin{tabular}{lllll}
\hline English items & explicit & quasi-explicit & implicit & zero \\
\hline I think & & & & \\
in my opinion & $44(88 \%)$ & $0(0 \%)$ & 4 & 2 \\
perhaps & $42(84 \%)$ & $8(16 \%)$ & 0 & 0 \\
\hline
\end{tabular}


The explicit realization of modality I think parallels with explicit realizations in Chinese in most cases ( $88 \%$ of the total). Here is one typical case:

[7.1] wǒ rènwéi gè duìxiàng gōngsī jiāng zǒu dào qìqŭ.

我认为各 对象 公司将走到一起

I think each object company will walk to together.

English text: I think the object companies will come together.

However, there are 4 instances in which the explicit realization corresponds to implicit realization in Chinese. The most frequent implicit realizations are kóngpà '恐怕afraid'. See one example below:

[7.2] xuānchuán gōngzuò huì̀̀ tíchū dăngxiào hé lúnxùn fēnkāi.

宣传工作 会议 提出 党校 和 轮训 分开

propaganda work conference propose Party-school and training separate.

kǒngpà zhègì yijiàn shì duì de.

恐怕这个意见是对的.

afraid this advice is correct PAR.

English text: At the conference on propaganda it was proposed that Party schools be separated from this training, which I think is the correct thing to do.

Moreover, two instances find no corresponding expressions in Chinese. The motivations for the translation shift are not clear. When the explicit modality is represented implicitly, the subjective orientation is lost. Thus the interpersonal equivalence is affected. Nevertheless, these cases are rare in my data.

As for quasi-explicit realizations of modality, $84 \%$ of the phrase in my opinion are manifested explicitly in Chinese as shown in example 7.3a.

[7.3a] wǒ kàn zhè zhǒng xì yăn yidiăn yě kéy̌̀.

我看这种戏演一点也可以

I see this MEA show perform a-bit also all-right.

English text: In my opinion, it is all right to stage some of them.

Only $22 \%$ are manifested quasi-explicitly. Consider the examples below:

[7.3b] jù wǒ kàn, xíngshì b̌̀ yìxiè rén qiáng,

据 我看,形势 比一些人强,

according-to I see situation than some person powerful.

shènzhì b̌̀ dà guan qiáng.

甚至 比大官强。.

even than big official powerful.

English text: In my opinion, circumstances are more powerful than individuals, even than high officials.

[7.3c] wŏde yìsĩ shì, yīnwèi jūnduì shòu de zànyáng tài duō le.

我的意思是, 因为军队受的赞扬太多了,

my opinion be because army be SUB praise too many ASP.

suóy̌̀ bù néng zhì bào xì bú bào yōu.

so NEG can only say happy NEG say sad.

所以不能只报喜不报忧。.

English text: In my opinion, we shouldn't talk only about the strong po[in]ts of our army to the neglect of its weaknesses, because it has been praised often enough.

In example 7.3b, a coverbal phrase jù wǒ kàn据我看 'according to me' is employed to construe the quasi-explicit modality. This strategy is used in 8 instances. In example 7.3c, 
modality is realized by a relational clause wǒde yisi shi我的意思是 'my opinion'. Thus, it is regarded as explicit modality. This strategy is used in 3 instances. It is surprising that quasi-explicit realizations are not paralleled between the two languages. The explicit realization occurs more frequently than quasi-explicit realization (84\% versus $16 \%$ ) in Chinese for quasi-explicit modality in English. In other words, most of the quasi-explicit modality in English is shifted into explicit orientation in Chinese. It seems that the difference between explicit and quasi-explicit realizations of modality is blurred in translators' bilingual knowledge. This phenomenon serves as strong evidence for the notion of 'quasiexplicit' modality as proposed in this study. In other words, the intermediate realization of modality that lies between explicit and implicit ends is close to the explicit end rather than the implicit end. It also supports the basic assumption in SFG that a prepositional phrase is a minor clause.

In the case of implicit modality, the adverbial group perhaps is mostly paralleled with implicit realizations in Chinese (76\%). Explicit or quasi-explicit realizations are not found in the Chinese texts to parallel with implicit modality in English. Notably, 24\% of the instances in English find no expression in Chinese texts. It reveals the fact that interpersonal meaning is often overlooked by the translator when the modality is implicit.

Another interesting issue is to examine how verbal groups such as shuōbúding '说不 定” and méizhŭn '没准' are translated into English because verbal groups cannot be used to construe modal Adjunct in English. The corpus mentioned above generates 13 instances for shuōbúding and 4 instances for méizhŭn (Table 12).

Most of the expression shuōbuiding parallels implicit modality in English. Below is one example:

[7.4a] shuō bú dìng shàngmiàn yǒu míngzì huòzhě shěnme.

说不定上面有名字或者什么

say NEG firm on have name or what.

English text: maybe its got a name on it or something.

Two instances correspond to explicit modality in English. It is translated into someone's knowledge about something.

[7.4b] xǔduō rén hěn dānxīn hàipà yǒukěnéng shuōbú dìng.

许多人很担心害怕 有可能说不定

many people very worry fear have-possibility say NEG firm.

shijiè mòrì zhēnde jiù zài nà yì tiān.

世界末日真的就在那一天。.

world end really just at that one day.

English text: many were afraid-afraid that perhaps-who knows-the world might end that very day.

The tendency is the same with the expression méizhŭn. The translation proves that the verbal group at issue realizes implicit modality. It differs from the adverbial group in the sense that it foregrounds the meaning of mental processes.

Table 12 Representation of 'shuōbúding' and 'méizhǔn' in parallel corpus

\begin{tabular}{lllll}
\hline $\begin{array}{l}\text { Realizations in English } \\
\text { Chinese items }\end{array}$ & explicit & quasi-explicit & implicit & zero \\
\hline shuōbúding & $2(15.4 \%)$ & 0 & $11(84.6 \%)$ & 0 \\
méizhün & $1(25 \%)$ & 0 & $3(75 \%)$ & 0 \\
\hline
\end{tabular}




\section{Conclusion}

The study has compared the system of ORIENTATION of modality in English and Chinese. The two languages share the same strategy in explicit and implicit orientations. Specifically, modality could be realized by units of various rank levels. Explicit modality is construed as Figure. Quasi-explicit modality is construed as projecting Circumstance. Implicit modality is construed as modal Adjunct, part of Process/Predicator, or mood elements. One systemic difference between English and Chinese is that the word that realizes implicit modality is the finite (verbal operator) in English while the word in Chinese is the verbal adjunct (verbal auxiliary). This leads to another major difference: in English, the implicitly subjective modality is realized by the finite whereas in Chinese, there is no such grammatical resource. Hence there is no need to distinguish subjective/objective orientations in implicit modality. In fact, the choice of subjective and objective orientation is most obvious in explicit modality (not in quasi-explicit or implicit modality) in Chinese. Another difference is that at the group rank, verbal groups can be used to construe modal Adjunct in Chinese while this phenomenon is not found in English. Nonetheless, in both languages, moving up the rank scale from implicit to explicit modality means expanding the meaning potential of modality. Finally, the parallel corpus shows that translation shifts mostly occur in quasi-explicit modality. That is, the modality realized quasi-explicitly in English is more often represented explicitly in Chinese texts. It proves that the term 'quasi-explicit', as proposed in this study, captures the semantic nature of modality realized by units at phrase rank.

\section{Endnotes}

${ }^{1}$ Modal auxiliaries here are analyzed as words that occupy the pre-Head position of a verbal group as proposed in Halliday and McDonald (2004: 314-315).

${ }^{2}$ The website of CCL corpus: http://ccl.pku.edu.cn:8080/ccl_corpus/index_bi.jsp

Abbreviations

Acc: according to; ASP: aspect; MEA: measure noun; NEG: negative; PAR: particle; SUB: subordination marker

Acknowledgements

I would like to thank Prof. Chang Chenguang and Prof. Liu Peifu for their general support.

This paper is part of the project "Circumstantiation of Projection in English and Chinese from the Functional

Typological Perspective (GD16XWW05)" financed by Office of Philosophy and Social Science in Guangdong Province.

Competing interest

The author declares that he has no competing interest.

Authors' information

Shu-Kun Chen is a lecturer in Guangdong University of Finance where he teaches English-Chinese translation and interpreting, college English, and cross-cultural communication. He has gained a PhD at Sun Yat-Sen University in Guangzhou, China. His research interests are discourse analysis, social semiotics and functional syntax. He has published in Foreign Language and Literature (2014), a journal issued by Xichuan International Studies University and Foreign Languages Research(2015), published by China Liberation Army University.

\section{Publisher's Note}

Springer Nature remains neutral with regard to jurisdictional claims in published maps and institutional affiliations. 
Chang, C.G. 2017. English idioms in a bilingual learner's dictionary. In Applying systemic functional linguistics: The state of the art in China today, ed. J.J. Webster and X. Peng, 321-336. London and New York: Bloomsbury Academic.

Chen, S.K. 2016. Circumstantiation of projection: Functional syntax of angle in English and Chinese. Ampersand 3: 71-82.

Fawcett, R.P., and G.W. Huang. 1995. A functional analysis of the enhanced theme construction in English. Interface. Journal of Applied Linguistics 10: 113-144.

Greenberg, J.H. 1995. The diachronic typological approach to language. In Approaches to language typology, ed. M. Shibatani and T. Bynon. Oxford: Clarendon Press.

Halliday, M.A.K. 2009. The Gloosy Ganoderm: Systemic functional linguistics and translation. Chin Translators J 1: 17-26. Halliday, M.A.K. 1956. Grammatical categories in modern Chinese. Trans Philos Soc: 177-224.

Halliday, M.A.K. 1994. An introduction to functional grammar. London: Edward Arnold.

Halliday, M.A.K., and C. Matthiessen. 2014. Halliday's introduction to functional grammar. London and. New York: Routledge.

Halliday, M.A.K., and E. McDonald. 2004. Metafunctional profile of the grammar of Chinese. In Language typology: A functional perspective, ed. A. Caffarel, J.R. Martin, and C.M.I.M. Matthiessen, 305-396. Amsterdam/Philadelphia: John Benjamins Publishing.

Hopper, P.J., and E.C. Traugott. 1993. Grammaticalization. Cambridge textbooks in linguistics. Cambridge: CUP.

Huang, G.W. 2017. Searching for metafunctional equivalence in translated texts. In Applying systemic functional linguistics: The state of the art in China today, ed. J.J. Webster and X. Peng, 285-306. London and New York: Bloomsbury Academic

Li, C.N., and S.A. Thompson. 1989. Mandarin Chinese: A functional reference grammar. California. California: University of California Press.

Li, E.S.H. 2007. A systemic functional grammar of Chinese. London and New York: Continuum.

Li, R. 2004. Modality in English and Chinese: A typological perspective. Universal-Publishers.

Liu, D.Q. 2002. 汉语中的框式介词 [Circumposition in Chinese], modern. Linguistics 4: 241-253.

Lyons, J. (1977). Semantics. V. 2. Cambridge university Press.

Martin, J. R., Matthiessen, C. M. I. M., \& Painter, C. 2010. Deploying Functional Grammar. Shanghai: The Commercial Press.

Matthiessen, C. 1995. Lexicogrammatical cartography: English systems. Tokyo: International Language Sciences Publishers.

Matthiessen, C. 2001. The environments of translation. In Exploring translation and multilingual text production: Beyond content, ed. E. Steiner and C. Yallop, 41-126. Berlin and New York: Mouton de Gruyter.

Matthiessen, C. 2014. Choice in translation: Metafunctional considerations. In Caught in the middle: Lanquage use and translation, ed. K. Kunz, E. Teich, S. Hansen-Schirra, S. Neumann, and P. Daut, 271-334. Saarbrücken: Saarland University Press.

Matthiessen, C. 2015. Multilingual studies in systemic functional linguistics: Theoretical and descriptive resources for undertaking description, comparison, translation studies and typology. In Paper presented at the paper presented at the 1st Tunisian systemic functional linguistics conference and workshop (TSFLCW). Hammamet: University of Sfax.

McDonald, E. 1996. The "complement" in Chinese grammar: A functional reinterpretation. In Functional descriptions: Theory in practice, ed. R. Hasan, C. Cloran, and D. Butt, 265-286. Amsterdam: Benjamins Publishing.

Palmer, F.R. 2014. Modality and the English modals. Routledge.

Quirk, R., Greenbaum, S., Leech, G., \& Svartvik, J. 1985. A comprehensive grammar of the English language. London/ New York: Longman.

Peng, L.Z. 2005. 现代汉语情态研究 [on modality of modern Chinese]. Doctoral dissertation. Shanghai: Fudan University. Thompson, G. 2014. Introducing functional grammar. 3rd ed. London: Routledge.

Thompson, S.A. 1973. Resultative verb compounds in Chinese: A case for lexical.rules. Language 49 (2): 361-379.

Tsang, Chui-Lim. 1981. A semantic study of modal auxiliary verbs in Chinese. Doctoral dissertation. California: Stanford University.

Wang, Y. 2008. A functional study of the evaluative enhanced theme construction in English. Singapore: Prentice Hall.

Wei, Z.J. 2008. 基于功能的英汉语情态隐喻对比研究 [a functional contrastive analysis of modal metaphor in English and Chinese]. Modern Foreign Languages 31 (3): 263-272.

$\mathrm{Xu}$, J.N. 2000. Expressive forms of Chinese tones and induction of the tone system. Journal of Peking University.

Yang, S., and C.G. Chang. 2011. 情态的系统功能语言学考量[reflections on modality in systemic functional grammar]. Foreign Lang Res 160 (3): 27-31.

Zhu, Y.S. 1996. Modality and modulation in Chinese. In Meaning and Form: Systemic Functional Interpretations, ed. M. Berry, C. Butler, and R. Fawcett, 183-210. Norwood: Ablex publishing corporation.

\section{Submit your manuscript to a SpringerOpen ${ }^{\circ}$ journal and benefit from:}

- Convenient online submission

- Rigorous peer review

Open access: articles freely available online

- High visibility within the field

- Retaining the copyright to your article

Submit your next manuscript at $\boldsymbol{s p r i n g e r o p e n . c o m ~}$ 